\title{
Evaluation of Physiochemical Parameters and Some Heavy Metals from Tannery Effluents of Sharada and Challawa Industrial Areas of Kano State, Nigeria
}

\author{
*A.N. Shaibu and A.A. Audu \\ Department of Pure and Industrial Chemistry, Bayero University, Kano, Nigeria \\ [Corresponding Author: E-mail: abdullahishaibu32@yahoo.com]
}

\section{ABSTRACT}

The evaluation of physicochemical parameters and some heavy metals was carried out from six different tannery companies at the industrial areas of Challawa and Sharada, using standard procedures. Temperature, $\mathrm{pH}$, conductivity and total dissolved solids(TDS) were determined using portable digital hand logging meter. The sulphate, phosphate, nitrate, arsenic contents were determined using UV Spectrophotometer, while chloride, dissolved oxygen (DO) and biochemical oxygen demand (BOD) contents were determined using titrimetric method, and the heavy metals by atomic absorption spectrometry. The mean temperature of the water ranged from $36.00-39.670 \mathrm{C}, \mathrm{pH}: 2.63-9.33$, conductivity: $336.33-12351.67 \mu \mathrm{S} / \mathrm{cm}$, TDS: $166.73-6017.67 \mathrm{mg} / \mathrm{L}$, sulphate: $114.00-466.67 \mathrm{mg} / \mathrm{L}$, phosphate: 0.29 - 12.80mg/L, chloride: 58.66 - 1577.87mg/L, nitrate: 6.03 - 33.43mg/L, DO: 2.60 $21.27 \mathrm{mg} / \mathrm{L}$ and BOD: $0.77-12.33 \mathrm{mg} / \mathrm{L}$. Water samples from the tannery effluents contained higher levels for both physicochemical parameters and heavy metals in untreated than treated. Cadmium and nickel were within the WHO limit for both treated and untreated while arsenic was within the limit for only treated effluent. Chromium and lead were above the WHO limit for both treated and untreated effluent. The parameters studied showed variations within the tannery companies and this may affect the Challawariver where this effluent is discharged which can have long term health effect on the aquatic animals and humans that depend on the river water for their daily activities.

Keywords: Biochemical Oxygen Demand, Dissolve Oxygen, Heavy Metals and Effluents

\section{INTRODUCTION}

Kano Sate is the second largest industrial center in Nigeria and the largest in Northern Nigeria. Due to the large number of privately owned medium and small scale industries in the state producing various items including textile materials, tanned leather, foot wares, cosmetics, plastics, enamel wares, pharmaceuticals, ceramics, steel rods, beverages, animal feeds, furniture, vegetable oil and agricultural implements, the state government established an industrial estates such as Sharada, Challawa and others to meet up with the rapid growing industrialization (Ibrahim, 2003).

Industrial liquid effluents are one of the principal sources of heavy metals responsible for environmental pollution (Solomonet al., 2015). The current scenario of sustainable environment is highly risked since most waterborne waste discharges from both domestic and industrial sources are channeled into natural water bodies (Karthicket al., 2014).

In recent years, large scale usage of chemicals in various human activities has grown considerably and pollution has assumed an escalating dimension due to the continual expansion of urbanization, industrial development and agricultural activities (Emmanuel and Adepeju, 2015). Water pollution by industrial effluent has been one of the vital issues of environmental concern today (Umaet al., 2016).

The wastewater from the treatment of hides and skin in industrial effluents contained high levels of metals, toxic chemicals and other undesirable substance. As such, among all the industrial wastes, tannery effluents are ranked among the highest pollutants (Umar et al., 2017).Several chemicals like $\mathrm{Cr}\left(\mathrm{SO}_{4}\right)_{3}, \mathrm{NaCl}, \mathrm{Ca}(\mathrm{OH})_{2}$, 
$\mathrm{H}_{2} \mathrm{SO}_{4}$ etc, are extensively used during leather manufacturing processes(Lakshmi and Malliga, 2014), hence, the effluent contain high levels of impurities.Tanneries generate wastewater in the range of 30-35 L/kg skin/hide processed with variable $\mathrm{pH}$ and high concentrations of suspended solids, BOD and COD (llouet al., 2014).

One of the major factors that affect the beneficial use of surface water such as rivers, streams and ponds for industrial, domestic and agricultural purposes are contamination and pollution due to anthropogenic or human activities (Mustaphaet al., 2015).Tannery effluents have been considered the most polluted industrial wastes as in most cases it contains high levels of metals which are very toxic to plants, animals, (Abdulmuminiet al.,2015; Nivedita and Raviraj, 2016). Thus, efforts have been made to appraise the quality status of waste water effluent of industrial processes(Bichi and Danazumi, 2010). Such efforts would prove the acceptability of the treatment processes used as well as provide guidance on the use of the treated waste effluent (Hayelon and Adhena, 2014; Varshaet al., 2017).

The aim of the research was to determine the level of some physicochemical parameters and heavy metals in the tannery effluent of Sharada and Challawa industrial areas of Kano State, Nigeria

\section{MATERIAL AND METHODS \\ Study area}

The study areas are Sharada and Challawa Industrial Area (Figure 1) of Kano State, Northern Nigeria.They arelocated on latitude 11058/ $11050 / \mathrm{N}$ and longitude range of $8031 /-8040 / \mathrm{E}$ at an average elevation of about $430 \mathrm{~m}$ above the mean sea level (Egwuonwu et al., 2011). The study areas,Sharada and Challawa industrial estates are located in Kumbotso and Municipal local Government areas respectively. They are bordered in the South and West by Madobi local Government, in the southwest by RimiGado, in the South by Dala and Gwale and in the East by Dawakin Kudu local government areas.

A gentle slope tending towards the south-west direction characterizes the study site. All the industries located in the area discharge their effluent into Challawa River located at about 2.0 $\mathrm{km}$ from Challawa industrial estate and about $20.0 \mathrm{~km}$ from Sharada industrial estate downstream from the cluster of industries. In Sharada phase I industrial estate, Kano Municipal, liquid effluent was collected from Unique tannery (UQT) and Laquat tannery (LQT) while in Challawaindustrial estate, Kumbotso local Government, samples were collected from GB tannery treated (GBTa), GB tannery untreated (GBTb), Fata tannery treated (FTa), Fata tannery untreated (FTb), Mamuda tannery treated (MDTa), Mamuda tannery untreated (MDTb) and BB tannery (BBT)

\section{Sampling}

Liquid effluent samples (treated and untreated) were collected from six tannery companies of Sharada and Challawa industrial estate. The untreated effluent was collected from the effluent storage chamber and the treated effluent was collected directly from the treatment plant. Both treated and untreated effluents were collected in $2 \mathrm{~L}$ and $4 \mathrm{~L}$ plastic containers. One $\mathrm{cm}^{3}$ concentrated $\mathrm{HNO}_{3}$ was added to sample in $4 \mathrm{~L}$ container to lower the $\mathrm{pH}$ to 2.0 and to maintain the stability of oxidation state of the metals in solution, and it was used for heavy metal analysis while the sample in the $2 \mathrm{~L}$ container for physicochemical analysis was refrigerated at $4{ }^{\circ} \mathrm{C}$ (APHA, 1992).

Physicochemical Analysis of Tannery Effluent The $\mathrm{pH}$ and temperature were measured at the site of sampling using mercury glass thermometer and $\mathrm{pH}$ meter (Jenway 370). Conductivity and total dissolved solid were measured with digital conductivity meter (DR/890) after calibration with $0.01 \mathrm{M} \mathrm{KCl}$.

The $\mathrm{NO}_{3}{ }^{-}, \mathrm{SO}_{4}{ }^{2-}$ and $\mathrm{PO}_{4}{ }^{3}$-were determined using portable data logging meter (DR/20-10) which 
was installed with program for the three anions. The program numbers $355,680,490$ were entered to display $500 \mathrm{~nm}, 450 \mathrm{~nm}$ and $430 \mathrm{~nm}$ for $\mathrm{NO}_{3}-\mathrm{SO}_{4}{ }^{2-}$ and $\mathrm{PO}_{4}^{3-}$ respectively. $10 \mathrm{~cm}^{3}$ of the water sample was taken into the meter cell, the content of one Nitra Ver 5 nitrate reagent was added and shaken to dissolve. The cell was was allowed to stand in the dark for five minutes and concentration in $\mathrm{mg} / \mathrm{L}$ nitrate was read on the meter. The same process was repeated for sulphate and phosphate using Sulfa Ver 4 and phosphate reagents respectively (APHA, 1992). Chloride, DO and BOD were determined by titrimetric methods (Ademorati, 1996).

\section{Digestion of Sample}

For sample digestion, $1000 \mathrm{~cm}^{3}$ of the pretreated effluent water sample was measured and $750 \mathrm{~cm}^{3}$ was transferred into a $1000 \mathrm{~cm}^{3}$ pyrex glass beaker and evaporated on a hot plate. When the volume had reduced, the remaining $250 \mathrm{~cm}^{3}$ was added and heating continued until the volume was about $50 \mathrm{~cm}^{3}$. The solution was allowed to cool and $20 \mathrm{~cm}^{3}$ of $0.1 \mathrm{M}$ nitric acid was added to the beaker and boiled on a hot plate at $85^{\circ} \mathrm{C}$ until a clear solution was obtained. The sample was allowed to cool and transferred into a $100 \mathrm{~cm}^{3}$ standard flask. The resulting solution was then made up to $100 \mathrm{~cm}^{3}$ mark with deionized water.
This was filtered into a $100 \mathrm{~cm}^{3}$ volumetric flask using filter paper. The blank was prepared in a similar way by digesting $1000 \mathrm{~cm}^{3}$ of deionized water in place of the sample (Akanet al., 2007b). The digested water sample was aspirated into the atomic absorption spectrophotometer (model: Varian AA240FS) and absorbance measured at the individual metal wavelength using the appropriate hollow cathode lamps of $\mathrm{Pb}, \mathrm{Cr}, \mathrm{Ni}$ and $\mathrm{Cd}$. Calibration curves for the different metals were generated from metal standard solutions, and from the result, the concentrations of metals in the samples were calculated.

The levels of arsenic in the water samples were determined as described by Basseteet al. (1983).

\section{Statistical Analysis}

All analyses were performed in triplicates and the results expressed as mean $\pm S D$. The excel data analysis was used. The differences in EC, TDS, $\mathrm{PO}_{4}^{3-}, \mathrm{SO}_{4}{ }^{2-}, \mathrm{Cl}^{-} \mathrm{NO}_{3}-\mathrm{DO}, \mathrm{BOD}, \mathrm{As}, \mathrm{Cd}, \mathrm{Cr}, \mathrm{Ni}$ and $\mathrm{Pb}$ concentrations among the different samplingpoints were tested by analysis of variance method, (ANOVA), Tukey test and tTest was used to determine pair wise differences betweenpoints. A value of $p<0.05$ was considered statistically significant.

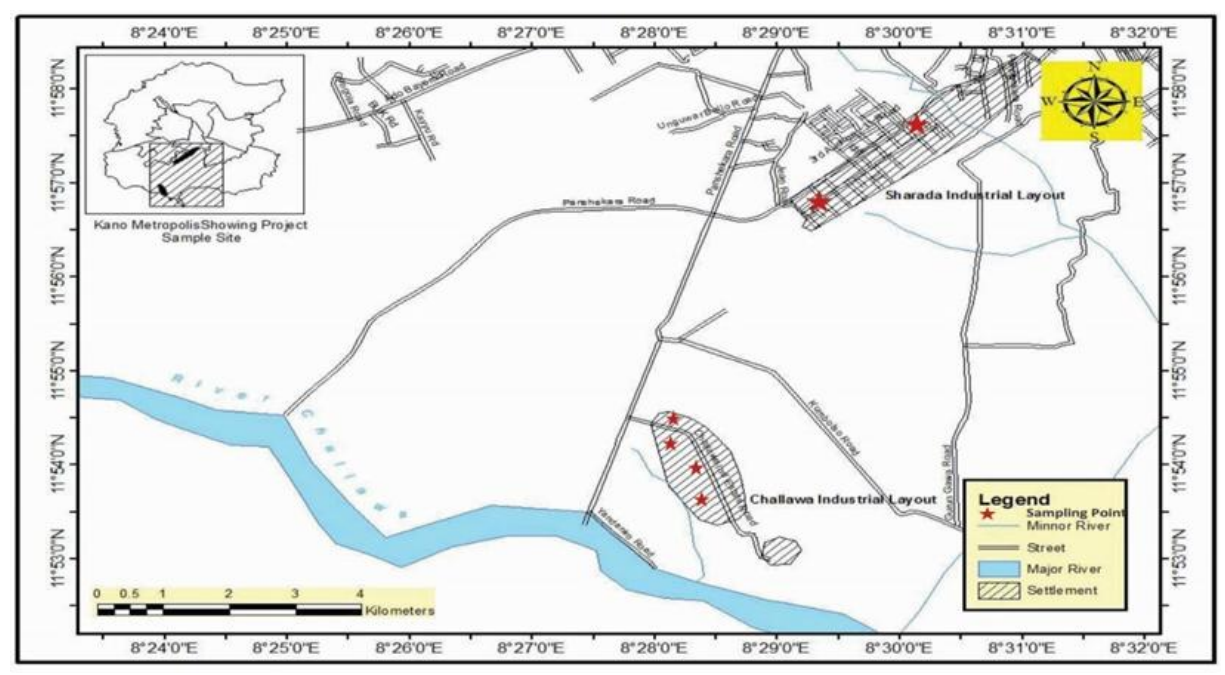

Figure 1: Map of Sharada and Challawa Industrial areas showing the sampling points 


\section{RESULTS AND DISCUSSIONS}

Temperature of the tannery effluents was found to be within the WHO and USEPAlimit $\left(<40^{\circ} \mathrm{C}\right)$ for all the tannery effluents discharged from the companies into the Challawa river body. The values ranged from $36.00 \pm 0.00-37.67 \pm 0.58^{\circ} \mathrm{C}$ for treated and $36.33 \pm 0.58-39.00 \pm 0.000^{\circ} \mathrm{C}$ for untreated (Table 1). This may be from boiled liquor used for leather processing and the values are in agreement with the work of Akan et al. (2007a).

The $\mathrm{pH}$ of the tannery effluents discharged into the Chalawa river body from the tanneries under study was low for untreated effluents $(2.63 \pm 0.15$

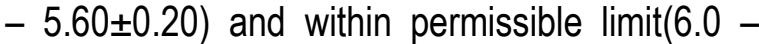
9.0), for treated effluents i.e. $8.53 \pm 0.06$ $9.33 \pm 0.64$, (Table 1), which indicates that treatment using biological method was efficient (Hayelon and Adhena, 2014; Mohamed et al., 2016). The low pH value in untreated effluents may be due to use of acids in the tannery processing. Arasappan and Kalyanaraman, (2015) reported $\mathrm{pH}$ of 7.08 and 7.07 for treated tannery effluent. The discharge of such effluent with acidic $\mathrm{pH}$ into ponds, rivers and streams for irrigation may be dangerous to aquatic biota such as zooplankton and fishes (Hemamalini and Sneha, 2014).

Untreated effluent showed higher levels of conductivity than treated (Figure 2).Both treated and untreated effluent have conductivity values above WHO limit of $1200 \mu \mathrm{S} / \mathrm{cm}$ except FTa and UQT, an indication that there were discharge of high levels ofcations and anions in the effluents, FTa and UQT may have efficient effluent treatment. There was no significant difference in conductivity values among sites GBTa, GBTb and MDTb. Similarly, conductivity levels at sites LQT wassignificantly higher than those obtained from the rest of the sampling sites and this may be attributed to poor treatment facility, while the value obtained at sites BBT, MDTa and FTBa are not significantly different from one another. The high conductivity of the effluents can alter the chelating properties of water bodies and createan

in-balance of free metals availability for flora and fauna (Akan et al., 2007a). This is in agreement with the study carried out by (Arasappan and Kalyanaraman, 2015; Noorjahan, 2014; Mohammed et al., 2017).

The total dissolved solids (TDS) values in the effluentsare shownin Figure 2. The TDS values for treated effluent were lower than untreated effluent. The value of untreated effluent was higher than the WHO/USEPA limit of $600 \mathrm{mg} / \mathrm{L}$. Sites GBTa, GBTb, MDTa, MDTb and BBT are not significantly different from one another but are slightly lower than the levels obtained at site LQT. This may be attributed to efficient effluent treatment at sites GBTa, GBTb, MDTa, MDTb and BBT.Total dissolved solids are mainly due to carbonates, bicarbonates, chlorides, sulphates, phosphates, nitrates, nitrogen, calcium, sodium, potassium, iron suspended solids from skin and dissolved processing salts(Kannanet al., 2009). This agreed with (Rajeswari 2015; Mohammed et al., 2017).The t-test showed strong positive correlation between conductivity and TDS ( $r=$ 0.9995), the higher the conductivity the higher the TDS, at $5.0 \%$ probability and $8.0 \%$ degree of freedom.

Table 1: Mean Temp. andpH, of the Tannery Effluents fromSharada and Challawa Industrial Areas.

\begin{tabular}{lll}
\hline $\begin{array}{l}\text { Sampling } \\
\text { Sites }\end{array}$ & Temp. ${ }^{\circ} \mathrm{C}$ & $\mathrm{pH}$ \\
\hline GBTa & $36.7 \pm 0.58$ & $8.53 \pm 0.12$ \\
GBTb & $36.7 \pm 0.58$ & $3.07 \pm 0.06$ \\
Fta & $36.0 \pm 0.34$ & $8.87 \pm 0.23$ \\
FTb & $36.3 \pm 0.23$ & $3.23 \pm 0.08$ \\
MDTa & $37.7 \pm 0.66$ & $9.33 \pm 0.60$ \\
MDTb & $39.7 \pm 0.85$ & $2.63 \pm 0.15$ \\
UQT & $38.0 \pm 0.66$ & $5.60 \pm 0.20$ \\
BBT & $39.0 \pm 0.76$ & $4.80 \pm 0.10$ \\
LQT & $38.0 \pm 0.59$ & $4.77 \pm 0.21$ \\
USEPA2004/ & $<40.0$ & $6.50-9.50$ \\
WHO, 2008 & & \\
\hline
\end{tabular}




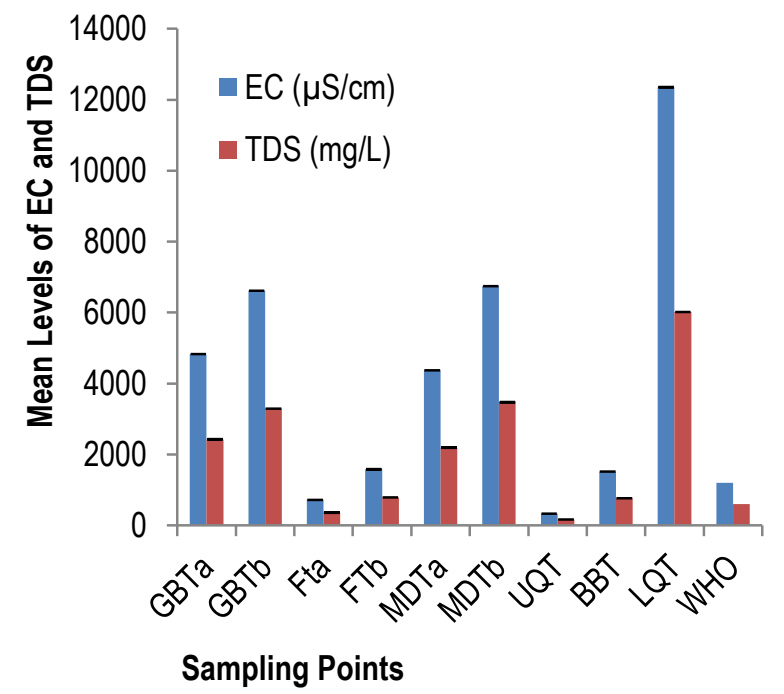

Figure 2: Mean Levels of EC and TDS in the Tannery effluents from Sharada and Challawa Industrial Areas

The Sulphate levels of the tannery effluents were higher in untreated than the treated (Figure 3). For untreated the value was $448.45 \pm 2.55 \mathrm{mg} / \mathrm{L}$ and for treated $246.78 \pm 2.28 \mathrm{mg} / \mathrm{L}$. The values were below the WHO maximum permissible limit (500mg/L) except BBT and MDTb for discharge of tannery effluent into rivers. The sulphate levels at sites GBTa, GBTb, FTb, BBT, and LQT showed no significant difference among the sites at $p<0.05$ while sites FTa, UQT, GBTa and MDTa were also not significantly different from one another, however, site UQT has the lowest sulphate concentration. The concentration of sulphate at site MDTb was significantly higher than those obtained from other sites except sites BBT, LQT and FTa.The high Sulphate level may be attributed to the excessive use of sulphuric acid and tanning powder containing high levels of Sulphate (Bosnicet al., 2000). This agreed with the studies conducted by (Akan et al., 2007a)

The phosphate values of the tannery effluents were below the WHO permissible limit of $5 \mathrm{mg} / \mathrm{L}$ for discharge of effluent into rivers except GBTa, GBTb and LQT (Figure 3). The phosphate levels in all the sampling sites showed no significant difference at $p<0.05$. The observed phosphate levels were in agreement with (Akan et
al.,2007a).Chloride level in the tannery effluent was higher in untreated effluent than the treated effluent. The value for untreated was higher than WHO maximum permissible limit $(600 \mathrm{mg} / \mathrm{L})$ for discharge of effluent into rivers(Figure 3). Chloride levels at sites MDTb and LQT were not significantly different from each other but were significantly greater than those obtained from other sites. The high chloride content may be due to the use of large quantities of common salt $(\mathrm{NaCl})$ in hide and skin preservation and pickling process. Sites FTa has the lowest chloride levels even though it was not significantly different from those obtained at sites UQT and BBT. The chloride values obtained agreed with the work of (Kawseret al., 2011; Rajeswari, 2015).

The nitrate content of the untreated tannery effluent was higher than the treated effluent (Figure 3). The nitrate levels in all the sites were not significantly different from one another at $p<0.05$ The high nitrate content in tannery effluent may be due to the presence of ammonia from deliming materials and nitrogen contained in protein materials from liming and hair removal process. ANOVA and Tukey test showed there was a significant difference between sulphate, phosphate, chloride and nitrate, $\quad(p<0.05)$ between the sampling sites.

The effluent mean dissolved oxygen concentrations were $13.51 \mathrm{mg} / \mathrm{L}$ for treated tannery effluent and $8.95 \mathrm{mg} / \mathrm{L}$ for untreated (Table 2). The dissolved oxygen levels at sites GBTa was significantly greater than the values recorded in other sampling sites though it was below the USEPA 2004; WHO 2008 limit of $50 \mathrm{mg} / \mathrm{L}$. Dissolved oxygen levels at sites GBT, FTa, MDTa, BBT and LQT were not significantly different from one another. The values observed is in agreement with (Akan et al., 2007a; Mohammed et al., 2017). Low dissolved oxygen in effluent when discharged into rivers has adverse effects on aquatic biota as less oxygen will be available for aquatic life. 


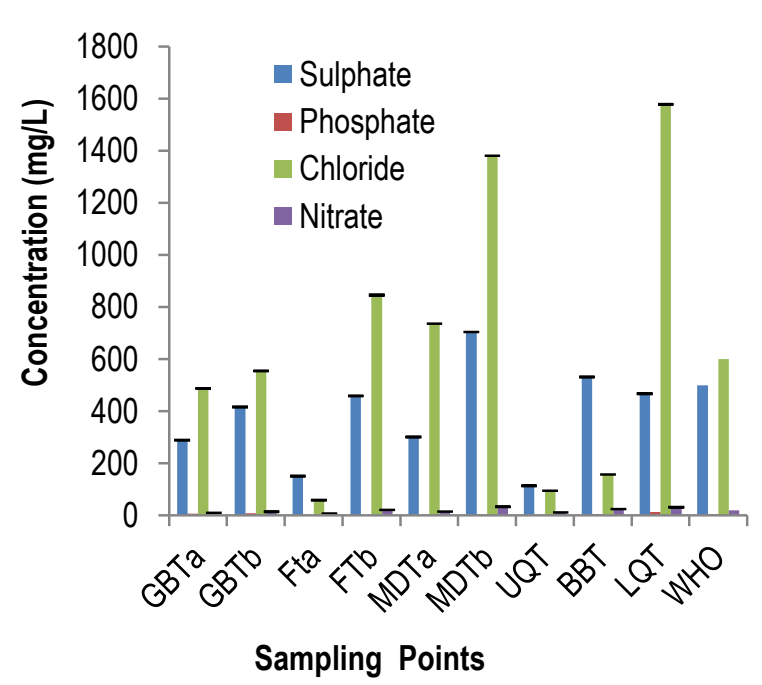

Figure 3: Mean Sulphate, Phosphate, Chloride and Nitrate of Tannery effluents from Sharada and Challawa Industrial Areas

Mean $B O D$ values for treated tannery effluent was $6.80 \mathrm{mg} / \mathrm{L}$ while that of untreated was $2.47 \mathrm{mg} / \mathrm{L}$ (Table 2). The BOD levels at sites GBTa was significantly different from those observed in other sites at $p<0.05$. The unhairing and tanning of hides and skin involved a lot of organic matters which gives rise to high BOD, and as a result, strips oxygen from polluted water and deprives aquatic life of oxygen for survival (Varshaet al., 2017). High level of BOD (600$1622 \mathrm{mg} / \mathrm{L}$ ) was observed by (Noorjahan, 2014). The t-test analysis indicated that there was positive correlation between DO and BOD ( $r=$ 0.767).

Arsenic concentrations in tannery effluents (Figure 4) showed that only GBTa, FTa, and MDTa have their arsenic levels within the USEPA 2004;WHO, 2008 threshold limit of $0.1 \mathrm{mg} / \mathrm{L}$ which ranges from $0.0659-0.1110 \mathrm{mg} / \mathrm{L}$ with treatment efficiency of $40.63 \%, 0.0545-0.1000 \mathrm{mg} / \mathrm{L}$ with $45.50 \%$ and $0.0955-0.1409 \mathrm{mg} / \mathrm{L}$ with $32.22 \%$ respectively, while other tanneries sampled were above the limit (NESREA, 2007). Arsenic levels in all the sites studied showed no significant difference. High arsenic concentration in tannery effluent may be attributed to the use of arsenic added to the float to reduce bacterial development in tanning process. Bhatnagaret al. (2013); Manjushree et al. (2013); Emmanuel and Abdul-qadir (2017) obtained similar arsenic levels in tannery effluent. Arsenic has toxic effect associated with lung, kidney, bladder, skin disorders and increased risk of cancer (ATSDR, 2003; Scragg, 2006).

Table 2: Mean DO and BOD of the Tannery Effluents from Sharada and Challawa Industrial Areas

\begin{tabular}{lll}
\hline Sampling Sites & $\mathrm{DO}(\mathrm{mg} / \mathrm{L})$ & $\mathrm{BOD}(\mathrm{mg} / \mathrm{L})$ \\
\hline GBTa & $21.3 \pm 0.29_{\mathrm{e}}$ & $12.3 \pm 0.21_{\mathrm{g}}$ \\
GBTb & $12.1 \pm 0.26_{\mathrm{cd}}$ & $4.07 \pm 0.17_{\mathrm{f}}$ \\
$\mathrm{Fta}$ & $9.03 \pm 0.17_{\mathrm{c}}$ & $0.77 \pm 0.09_{\mathrm{f}}$ \\
$\mathrm{FTb}$ & $2.60 \pm 0.16_{\mathrm{a}}$ & $4.40 \pm 0.12_{\mathrm{f}}$ \\
$\mathrm{MDTa}$ & $10.2 \pm 0.20_{\mathrm{c}}$ & $1.30 \pm 0.08_{\mathrm{f}}$ \\
MDTb & $14.1 \pm 0.22_{\mathrm{d}}$ & $3.67 \pm 0.12_{\mathrm{f}}$ \\
UQT & $5.10 \pm 0.13_{\mathrm{ab}}$ & $3.37 \pm 0.17_{\mathrm{f}}$ \\
BBT & $8.43 \pm 0.16_{\mathrm{bc}}$ & $2.27 \pm 0.12_{\mathrm{f}}$ \\
LQT & $11.3 \pm 0.21_{\mathrm{c}}$ & $3.03 \pm 0.14_{\mathrm{f}}$ \\
USEPA2004/ & 50 & 100 \\
WHO, 2008 & \\
Least Significant Difference $(\mathrm{LSD})=3.934$ \\
Mean with different letter(s) are statistically significant \\
p<0.05
\end{tabular}

Cadmium concentrations in tannery effluents samples were as show in (Figure 4). From the figure it can be seen that all the effluents had their cadmium concentrations below the WHO maximum permissible limit of $1.0 \mathrm{mg} / \mathrm{L}$ with the range of $0.0205-0.0470 \mathrm{mg} / \mathrm{L}$ and treatment efficiency of $56.38 \%$. Cadmium levels do not also differed significantly in all the sampling sites.Manjushree et al., (2013 Simul-Bhuyan and Shafmentaliqul-Islam (2017); Mohammed et al., (2017) obtained similar Cd levels in tannery effluents and treatment efficiency of $33.25 \%$. $0.07 \mathrm{mg} / \mathrm{L}$ and $0.081 \mathrm{mg} / \mathrm{L}$ were reported by (Sahuet al., 2007; Amanial, 2015).

Chromium concentrations in the tannery effluents are shown in Figure 4, it can be observed that 
chromium level in all the sites were higher than the WHO maximum permissible limit of $1.0 \mathrm{mg} / \mathrm{L}$ except GBTa $(0.625 \pm 0.01) \mathrm{mg} / \mathrm{L}$ and $\mathrm{FTa}$ $(0.925 \pm 0.01) \mathrm{mg} / \mathrm{Lwith}$ treatment efficiency of $56.14 \%$ and $30.18 \%$ respectively. The drop in the treatment efficiency may be due to improper maintenance of the treatment plant or used of substandard chemicals. The levels of chromium insiteMDTb was significantly greater than those recorded in other sites, while the levels in sites GBTa, GBTb, MDTa, BBT and LQT were not significantly different from one another at $p<0.05$. Range of $1.26-2.17 \mathrm{mg} / \mathrm{L}$ and $1.55 \mathrm{mg} / \mathrm{L}$ were also reported by Sahuet al., (2007); Monika et al., (2011). Higher range of $3.33-5.79 \mathrm{mg} / \mathrm{L}$ was also reported by Bernard and Ogunleye (2015).Values of $5.56 \mathrm{mg} / \mathrm{L}$ and $7.21 \mathrm{mg} / \mathrm{L}$ were reported by Bhatnagaret al. (2013) and Deepali (2010) respectively. The higher values of chromium may be attributed to large amount of chromium salt(chromium sulphate) used in tannery tanning operations (Modal et al., 2005; USEPA, 2010;). At high concentration and long term exposure, chromium can cause cancer (IARC, 2012).

Nickel concentration in the tannery effluentsispresented in Figure 4. From the results it showed that nickel concentrations in all the tannery effluents were below the WHO permissible limit of $1.0 \mathrm{mg} / \mathrm{L}$ with range 0.0029 $0.0144 \mathrm{mg} / \mathrm{L}$ and treatment efficiency of $79.86 \%$. Range of $0.004-0.0095 \mathrm{mg} / \mathrm{L}$ was reported by Monika et al. (2011). Other values reported in literatures were $0.05 \mathrm{mg} / \mathrm{L}, \quad 0.68 \mathrm{mg} / \mathrm{L}$ and 0.85mg/L (Sahuet al., 2007;Bhatnagaret al., 2013; Amanial, 2015) respectively. There was no significant difference in the levels of nickel in all the sites. The presence of nickel in tannery effluent may be attributed to chemicals used in the tanning and post tanning processing of leather (UNIDO, 2005). At high concentration, nickel may cause damage to DNA and cell structures (Monika et al., 2011).

Lead concentrations in all the tannery effluents were above WHO (2008) limit of $0.1 \mathrm{mg} / \mathrm{L}$ (Figure 4) with the range of $0.6250-0.8501 \mathrm{mg} / \mathrm{L}$ and treatment efficiency of $26.48 \%$. Lead levels in FTa was significantly lower than those observed in the other sites while those recorded at sites GBTa, FTb, MDTa and UQT were not significantly different from one another. A range of $0.67-3.10 \mathrm{mg} / \mathrm{L}$ was reported from the same study area (Bernard and Ogunleye, 2015). Lead affects central nervous system, particularly in children and also damages liver, kidney and the immune system and at higher concentration lead may result in metallic poisoning which can possibly cause cancer in human (Bakareodunola, 2005). Results indicated significant difference $(p<0.05)$ among the metals $(A s, C d$, $\mathrm{Cr}, \mathrm{Ni}$ and $\mathrm{Pb}$ ) in effluents from the different tannery companies in Sharada and Challawa industrial area,

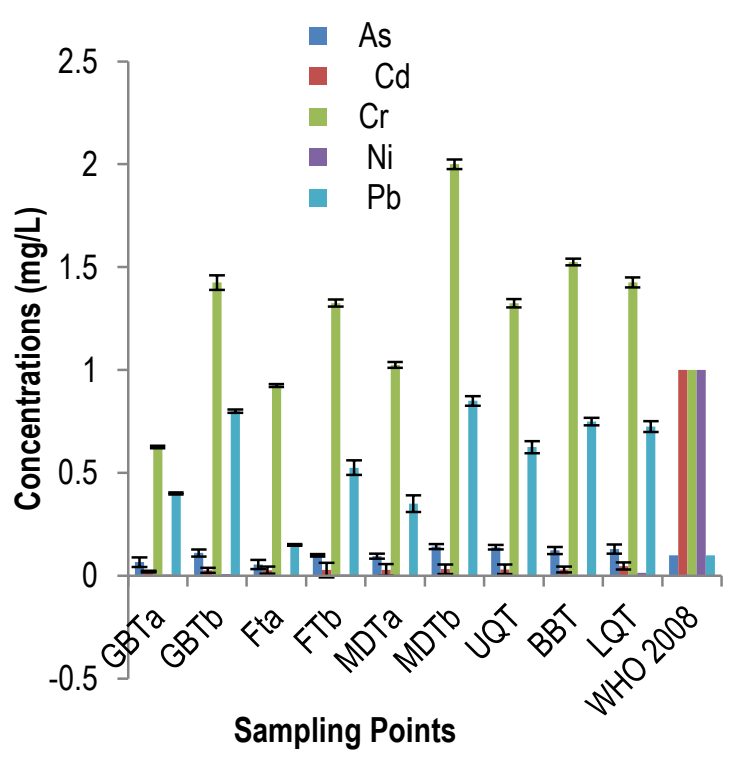

Figure 4: Concentrations of $\mathrm{As}, \mathrm{Cd}, \mathrm{Cr}, \mathrm{Ni}$ and $\mathrm{Pb}$ in the Tannery effluents from Sharada and Challawa Industrial Areas.

\section{CONCLUSION}

The results of physicochemical parameters and heavy metals content in tannery effluent samples were found to be high in untreated than treated. These results indicated that treatment methods employed by some of the tannery companies in treating their effluents do not remove the parameters and heavy metals to WHO, USEPA, NESREA and FEPA permissible level before 
discharging the effluent into the river, and these could have serious environmental andhealth effects.

\section{REFERENCES}

Abdulmumini, A., Abubakar, I.T., Magaji, L., Sani M.G., Ayuba, A.M., Shehu, H., Isa B.K. (2015). A Review on Industrial Effluents as Major Sources of Water Pollution in Nigeria.Chemistry Journal, 1(5): 159-164.

Ademorati, M.A. (1996). Standard Methods for Water and Effluent Analysis.Foludex Press Ltd, Ibadan. $1^{\text {st }}$ ed. Pg 80-83.

ATSDR, (2003).Agency for Toxic Substance and Disease Registry ATSDR, (2003)Toxicological Profile for Arsenic U.S. Department of Health and Humans Services, Public Health Humans Services, Centers for Diseases Control, Atlanta.

Akan, J.C., Moses, E.A., Oubuaja, V.OandAbah, J. (2007a). Assessment of Tannery Industrial Effluent from Kano Metropolis, Kano state, Nigeria. Journal of Applied Sciences, 7:27882793.

Akan, J.C., Ogugbuaja, V.O., Abdulrahman, F.I and Ayodele, J.T. (2007b). Determination of pollutant Levels in Water of River Challawa and in Tap Water from Kano Industrial Area, Kano State, Nigeria. Research Journal of Environmental Sciences, 1: 211-219

Amanial, H. R. (2015). Study on the pollution levels of trace metals from modjo tannery effluent in the surrounding river water and soil. Science Journal of Analytical Chemistry,3(5) 56-60.

APHA, (1992).American Public Health Association Standard Methods for Examination of Water and Wastewater; 18th edition, Academic, pg. 80-89. Washington, DC.

Arasappan, S. and Kalyanaraman R. (2015).Characterization of Physicochemical Parameters and heavy metal Analysis of Tannery Effluent. International Journal of Current Microbiology and Applied Sciences, 4(9): 349-359.
Bakare-Odunola. M. T. (2005). Determination of some metallic impurities present in soft drinks marketed in Nigeria. The Nigerian Journal of Pharmacy, 4(1): 51-55.

Bassete, J., Denney, RC., Jefferg, GH. andMendhan, J. (1983). Vogel's Textbook of Quantitative Inorganic Analysis, 4th edition Longman New York, Pp. 451-453.

Bernard,E.; Ogunleye, A. (2015).Evaluation of tannery effluent content in Kano metropolis, Kano State Nigeria. International Journal Physical Science,10(9): 306-310,

Bhatnagar, M.K., Singh, R.,Gupta, S., Bhatnagar, P. (2013). Study of tannery effluents and its effects on sediments of river ganga with special to heavy metals at Jajmau, Kanpur. India Journal of Environmental Research and Development, 8(1):56-59.

Bichi, M.H. and Danazumi, S. (2010). Industrial pollution and heavy metals profile of Challawa River in Kano. Journal of Applied Sciences in Environment Sanitation, 5(1): 2329.

Bosnic M., Buljan J. and Daniel, R.P. (2000).Regional program for pollution control. Tanning Industry US/RAS/92/120, SouthEast Asia, Pg: 1-14.

Deepali, K. K. (2010). Metals Concentration in Textile and Tannery Effluents Associated Soils and Ground Water. New York Science Journal, 3(4): 82-89.

Emmanuel, $\mathrm{B}$ and Abdul-Qadir, I (2017).Effectiveness of Treatment Plants and Determination of Heavy Metals Concentration in Tannery Effluents in Kano, Kano State, Nigeria. International Journal of Modern Chemistry, 9(1):100-110.

Emmanuel, B. and Adepeju, O. (2015).Evaluation of tannery effluent content in Kano metropolis, Kano State Nigeria. International Journal of Physical Sciences, 10(9): 306-310.

Egwuonwu, G.N., Olabode, V.O., Bukar, P.H., Okolo, V.N. and Odunze, A.C. (2011).Characterization of Top Soil and Groundwater at Leather Industrial Area, Challawa, Kano, Northern Nigeria. Pacific 
Journal of Science and Technology, 12(1): 628-631.

Hayelon, D. and Adhena, A. (2014). Tannery Waste Water Treatment; International Journal of Emerging Trends in Science and Technology, 1(9):1488-1494.

Hemamalini, V. and Sneha, S. (2014). Biodiversity Characterization of bacterial and fungal isolates from gold electroplating effluent. Journal of Applied Environmental Microbiology, 2: 212-219.

IARC. (2012). Some Drinking Water Disinfectants and Contaminants, including Arsenic.Lyon, France, International Agency for Research on Cancer.IARC Monograph on the Evaluation of Carcinogenic Risks to Humans,.84.

Ibrahim A.K. (2003). Brief History of Kano 1999 to 2003. Kanostate.net. Kano State Government, Nigeria. Archived from the Original on 2009-12-10.Retrieved 2009-1207.Accessed on 2017-11-23.

llou, I., Souabi, S. and Digua, K. (2014). Quantification of Pollution Discharges from Tannery Wastewater and Pollution Reduction by Pre-Treatment Station. International Journal of Science and Research, 3(5): 17061715.

Kannan, K., Raajasekaran, G., Raveen, R. (2009). Bacterial analysis of soil samples collected in and around a sugar mill in Tamilnadu. Journal of Ecobiology, 24: 191195.

Kawser, M.A., Monika, D., Monirul, I.M., Mosammat, S.A., Shahidul, I and Muhammad, A.A. (2011). Physicochemical properties of Tannery and Textile Effluents and Surface water of River Buriganga and Karnatoli, Bangladesh.World Applied Sciences Journal, 12(2): 152-159

Karthick S., Jenifer P. R. M., Suganthapriya, K. and Sudhakar, M. (2014).A study on Assessment of Physicochemical properties of water and wastewater.International Journal of Engineering Science and Innovative Technology, 4(2): 173-177.

Lakshmi,K. and Malliga, P. (2014). Treatment of Tannery Effluent using Cyanobacterium
(Lyngbya Sp.) with Coirpith.International Journal of Scientific Research,4(9): 414-416.

Manjushree, C., Mostafa, M.G., Tapan, K.B and Ananda, K.S. (2013). Treatment of leather industrial effluents by filtration and coagulation processes. Journal of Science Direct, Water Resources and industry, 3: 1122

Modal, N.C., Saxena, V.K.and Singh, V.S. (2005). Impact of pollution due to tanneries on groundwater regime.Current. Science Journal, 88: 25.

Mohammed, N.A., Walid, S.A.andHisham, S.A. (2016).Biological Treatment of Leather Tanneries Wastewater Effluent-Bench Scale Modeling. International Journal of Engineering Science and Computing, 6: 2271-2286.

Mohammed, M.K., Fakhruddi, A.N., Chowdhury, M.A.Z., Fardous, $Z$ and Rasheedul, T. (2017).Characterization of tannery effluent of Hazaribagh area, Dhakar, Bangladesh.Journal of Pollution, 3(3): 395406.

Monika, D., Kawser, A., Shahidul, I. and Mosammat, S. (2011). Heavy Metal in Industrial Effluents (Tannery and Textile) and Adjacent Rivers of Dhaka City, Bangladesh.Terrestrial and Aquatic Environmental Toxicology, 5(1): 8 -13.

Mustapha, B.I., Khalid, D.K. and Zakari, A. (2015).Comparative Assessment of Heavy Metals Concentration in the Soil in the Vicinity of Tannery Industries, Kumbotso Old Dump Site and River Challawa Confluence, at Challawa Industrial Estate, Kano State, Nigeria. International Journal of Innovative Research \& Development, 4(6): 122-128.

NESREA, (2007).National Environmental Standards and Regulation Enforcement Agency (Establishment) ACT 2007, No.25.

Nivedita, A. and Raviraj, S. (2016).Study of Heavy and Transition Elements in Tannery Effluents and its Impact on Soil around Kanpur, India.International Journal of Scientific \& Engineering Research, 7(3): 1-6. 
Noorjahan, C.M. (2014). Physicochemical Characteristics, Identification of Fungi and Biodegradation of Industrial Effluent. Journal of Environmental Earth Science, 4: 32-39.

Rajeswari, R. (2015). Efficiency of effluent treatment and assessment of water quality parameters in tannery wastes. European Journal of Experimental Biology, 5(8): 49-55.

Sahu, R. K.Katiyar, S.; Tiwari, J. and Kisku, G. C. (2007).Assessment of drain water receiving effluent from tanneries and its impact on soil and plants with particular emphasis on bioaccumulation of heavy metals. Journal of Environmental Biology, 28(3): 685-690.

Scragg, A. (2006). Environmental Biotechnology, Oxford University Press, Oxford, UK, 2nd edition, pg. 415.

Simul-Bhuyan M.D and Shafmentaliqul-Islam M.D (2017).A Critical Review of Heavy Metal Pollution and Its Effects in Bangladesh.Journal of Environmental and Energy Economics, 2(1):12-25.

Solomon, S., Yadessa, C., Girma, T. and Daniel, F. (2015). Heavy Metal Concentrations andPhysicochemical Characteristics of Effluent along the Discharge Route from Hawassa Textile Factory, Ethiopia. Journal of Environmental Analytical Toxicology, 5(4): 17.
Uma, T., Saravanan N., Jothi-Narendiran N. (2016). Comparative analysis of physicochemical characters and heavy metals in dye industry effluent and sugarcane industry effluent along with lake water. International Journal of Fauna and Biological Studies,3(3): 81-83.

Umar, I.M, Ibrahim, M.A, Mustapha, M.B., Mohammed I.B., TashiObafemi U.T and Ahmad, G.I. (2017). Physicochemical Analysis and Microbiological Assessment of Tannery Effluent Discharged from Tanneries around Nigeria's Kano Industrial Estates.Journal of Advances in Microbiology, 2(1): 1-12.

UNIDO, (2005). United Nation Industrial Development Organization Cost of Tanned Waste Treatment, $15^{\text {th }}$ Session of the Leather and Leather Products Industry Pannel, Leon, Mexico.

USEPA, (2010).United States Environmental Protection Agency. Risk-Based Concentration Table.Region 3 Fish Tissue Screening Levels.

Varsha C., Devyani, S. and Bhawana, P. (2017). A Review: physiochemical analysis of industrial waste water. Indian Journal of Scientific Research, 13(2): 208-216.

WHO, (2008). Guideline for drinking water Quality. World Health Organization, Geneva. 